\title{
The Properties of Nitrogen Gas Breakdown Voltage under Direct Current Positive Polarity
}

\author{
Fri Murdiya* \\ Department of Electrical Engineering \\ Universitas Riau \\ Pekanbaru, Indonesia
}

\author{
Firdaus \\ Department of Electrical Engineering \\ Universitas Riau \\ Pekanbaru, Indonesia \\ Eddy Hamdani \\ Department of Electrical Engineering \\ Universitas Riau \\ Pekanbaru, Indonesia
}

\author{
Tumpal Pardede \\ Department of Electrical Engineering \\ Universitas Riau \\ Pekanbaru, Indonesia
}

*corresponding author: Fri Murdiya, frimurdiya@eng.unri.ac.id

\begin{abstract}
The type of insulation gases that are usually used in the power circuit breaker (circuit breaker) is the sulfur hexafluoride $\left(\mathrm{SF}_{6}\right)$ gas, nitrogen $\left(\mathrm{N}_{2}\right)$ and carbon dioxide $\left(\mathrm{CO}_{2}\right)$. Most of the electric power systems are using insulating materials such as sulfur hexafluoride $\left(\mathbf{S F}_{6}\right)$. Sulfur hexafluoride gas $\left(\mathbf{S F}_{6}\right)$ has a higher dielectric strength than the air. However, Sulfur hexafluoride $\left(\mathrm{SF}_{6}\right)$ gas is not friendly environmentally and very impact on global warming. The purpose of this study was to test the breakdown voltage of nitrogen gas $\left(\mathrm{N}_{2}\right)$ (more friendly environmental) as alternative insulation of sulfur hexafluoride $\left(\mathrm{SF}_{6}\right)$ gas. This study was used sphere and needle electrodes with a distance of 0.5-2 cm and a pressure of 1-4 bar; it was tested for 20 times. From the test results, it obtained that the breakdown voltage of sphere electrodes is more significant than the needle electrodes. Sphere and needle electrodes with a distance of $2 \mathrm{~cm}$ and a pressure of 4 bar have a most excellent value of breakdown voltage at the voltage of $140 \mathrm{kV}$ and $79 \mathrm{kV}$, respectively.
\end{abstract}

Keywords- electrodes, nitrogen gas $\left(N_{2}\right)$, weibull distribution, dielectric strength, breakdown voltage.

\section{INTRODUCTION}

The insulation is one of the crucial tools in a power system that is used to separate the electrical conductor wire; thus, so far there is no electricity leap. Failure occurs when the equipment is working abnormally; it can be damage to the machine. So, the continuity of the system is not running correctly. Insulation should be able to endure the breakdown voltage from the high voltage [1]. Air is one of the insulating gases that are used for high voltage electrical equipment. The dielectric strength of the gas insulation is lower than the solid insulation and liquid insulation. The insulation of gas is typically used by technicians or people in general, namely $\mathrm{SF}_{6}$, $\mathrm{N}_{2}$ and $\mathrm{CO}_{2}[2]$.

Most of the electric power systems used the gas insulating materials such as $\mathrm{SF}_{6}$ gas. $\mathrm{SF}_{6}$ gas has a higher dielectric than the air dielectric strength. However, $\mathrm{SF}_{6}$ gas is not friendly environmentally; thus, the research is necessary to find out the alternative friendly environmentally gas instead of $\mathrm{SF}_{6}$ gas, such as $\mathrm{SF}_{6}$ mixed $\mathrm{N}_{2}, \mathrm{SF}_{6}$ mixed $\mathrm{N}_{2}$, and $\mathrm{O}_{2}$ and other gases. The electricity industry has successfully used sulfur hexafluoride (SF6) as insulating gas of electric power. Then the insulation is done by combining gas with nitrogen gas $\left(\mathrm{N}_{2}\right)$ and can be a suitable replacement for the electrical insulation such as gas insulated lines (GIL) [3]. Sulfur hexafluoride $\left(\mathrm{SF}_{6}\right)$ has been widely used for insulation in high voltage insulation, such as the gas insulated switchgear (GIS), gas circuit breaker (GCB). While the insulation media must be friendly environmentally insulating gas such as set up by the climate conference in Kyoto [4]. The research and experiment have been done to find a replacement of $\mathrm{SF}_{6}$ insulating gas, as an alternative is by using nitrogen gas $\left(\mathrm{N}_{2}\right)$ is more environmentally friendly material.

High-voltage system is now widely grown and the magnitude of the voltage used in the transmission and distribution of electrical power as well as improved the insulation used. Therefore, it takes an insulation system that ensures no direct contact between the poles with a high voltage conductor. However, an insulator can be reduced reliability due to natural influences like rain [5]. The insulation is an essential part of the electric power system. The insulation serves to separate two or more voltage conductor of electricity, so there is no electricity or arcing leaps. Insulation is divided into three types, and they are insulating gas, liquid, and solid. The type of insulation can be used according to what they need to isolate [6]. The ability of the insulation withstand voltage has certain limits following the constituent material and the surrounding environment. When the applied voltage exceeds the field strength there will be break insulation down, it can be caused the current flow between the high voltage equipment and the equipment body or ground, and then, the short circuit will occur[7]. Gas insulation is very widely used at this time. Air, sulfur hexafluoride $\left(\mathrm{SF}_{6}\right)$, Carbon dioxide $\left(\mathrm{CO}_{2}\right)$ and vacuum insulating gas are types of insulation that are already widely used. The extensive used to cause the insulating material problem, so, it is needed research before 
they can be used [8]. The air at the atmospheric pressure is an insulating gas that is most commonly used. The gas insulation breakdown voltage occurs because of the collision of ions is called ionization. The electrons in the electron ionization can double back exponentially, and if the voltage is large enough, it can be caused the more significant damage to the insulation gas. For examples, gas insulating which has high dielectric strength is sulfur hexafluoride $\left(\mathrm{SF}_{6}\right)$, nitrogen $\left(\mathrm{N}_{2}\right)$ and carbon dioxide $\left(\mathrm{CO}_{2}\right)$. [9]

Breakdown voltage is a situation when the electric field is increased (voltage continuously increased), the atoms will be ionized. When the limits of the insulation withstand voltage, then the insulator will be changed into a conductor. When this happens is called the critical breakdown voltage. The breakdown voltage test is required to determine the essential point of insulation [10]. The analysis of gas insulation breakdown voltage is by using several kinds of electrodes; one of them is sphere electrodes. Standard of sphere electrodes consisting of two ball electrodes are arranged on one axis with the distance of the two electrodes can be arranged. The rated voltage breakdown for ac voltage, dc voltage or impulses voltage is maintained depending on the condition (i.e., air condition did not change). These air dielectric properties were used as the basis of measurement of high voltage with standard sphere electrodes [11].

\section{RESEARCH METHODOLOGY}

\section{A. $\mathrm{N}_{2}$ Gas Insulation Preparation}

This research was begun with the setting of the sidelines of the electrodes. The electrodes used in this study are sphere and needle electrodes. The steps of work will be explained the point to point such as 1.) The test tube is opened to set the sidelines of the electrode from the outside. 2.) Electrodes used in the experiment were mounted on a test tube. 3.) The distance sidelines of electrodes arranged to start from a distance of $0.5 \mathrm{~cm}, 1.0 \mathrm{~cm}, 1.5 \mathrm{~cm}$, and $2.0 \mathrm{~cm}$. 4.) Test tube put back until tight to prevent leakage when filled nitrogen gas $\left(\mathrm{N}_{2}\right)$. 5.) The tube must avoid the alien gas by the vacuum pump. Once the electrodes are installed and the distance interrupted electrodes arranged in a test tube, then it can be followed by entering nitrogen gas $\left(\mathrm{N}_{2}\right)$ in a test tube of refill tube with a weight of $20 \mathrm{~kg}$ by using a hose. The hose must be forceful against the gas pressure. 6.) The tension in the test tube is the boundary to 4 bar. The maximum pressure that can be inserted into the test tube at 6 bar. However, in this study, we only used 4 bars to prevent damage from the test tube tool. 7.) This study uses a pressure of 1 bar, 2 bars, 3 bars, 4 bars. Initially tested with the most considerable gas pressure are 4 bars and then reduced pressure until the pressure becomes 1 bar by slowly opening the faucet drain on the test tube.

\section{B. Gas Insulation Breakdown Test}

The high voltage test by using a high-voltage transformer HV 9105 Terço made in Sweden. The tools and research materials used in the analysis are: Transformer test (HV test transformer), control desk, diodes (rectifiers), the capacitor (smoothing capacitor), resistance (measuring resistor), insulating rod, connecting cup, floor pedestal, connecting rods, electrodes, grounding (earthing switch) and test tubes. Figure 1 is presented a test series of gas breakdown voltage under DC voltage positive polarity.

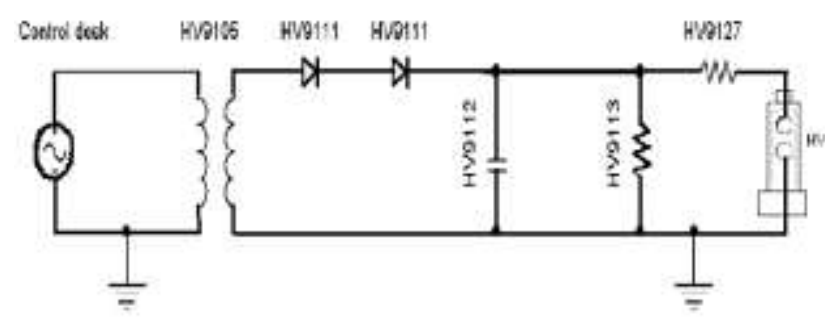

Figure 1. DC voltage generator test circuit

\section{DATA ANALYSIS AND DISCUSSION}

\section{A. Data}

The data was processed using the Weibull distribution method refer to [12] and through the data processing program, i.e. Microsoft Excel to view the graph breakdown voltage of insulating nitrogen gas $\left(\mathrm{N}_{2}\right)$ and air. Tests carried for 20 times for each variable by using two kinds of electrodes with different distances and different pressures.

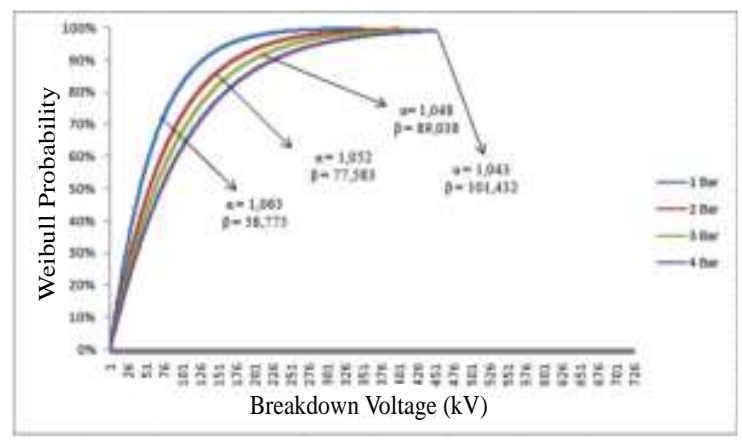

Figure 2. Curve for insulation breakdown voltage of nitrogen gas $(\mathrm{N} 2)$ with sphere electrodes, gap of $0.5 \mathrm{~cm}$ and gas pressure 1-4 bar.

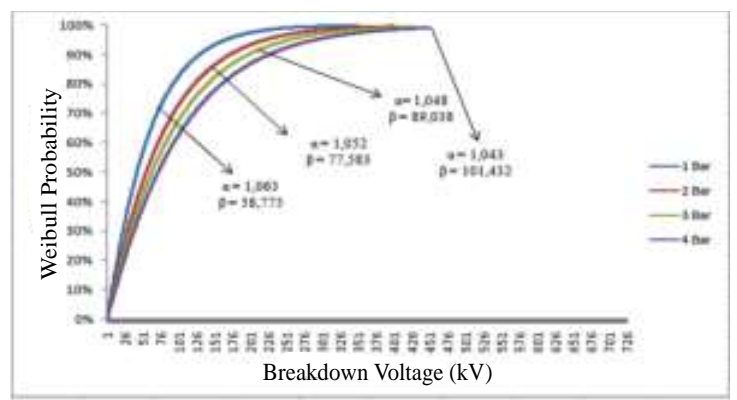

Figure 3. Curve for air breakdown voltage with sphere electrodes, the gap of $0.5 \mathrm{~cm}$ and gas pressure of 1-4 bar.

Based on Figure 2, it seem that the insulation of nitrogen gas $\left(\mathrm{N}_{2}\right)$ with sphere electrodes and the electrodes gap of 0.5 $\mathrm{cm}$, the Weibull probability of $100 \%$ is obtained when breakdown voltage of $350 \mathrm{kV}$ at 1 bar pressure, $400 \mathrm{kV}$ at a pressure of 2 bars, $425 \mathrm{kV}$ on 3 bars pressure and $450 \mathrm{kV}$ at a pressure of 4 bars, respectively. Figure 2 also showed that the Weibull probability of $50 \%$ was obtained for breakdown voltage of $42 \mathrm{kV}$ at a pressure of $1 \mathrm{bar}, 55 \mathrm{kV}$ at a pressure of 2 bars, $63 \mathrm{kV}$ at a pressure of 3 bars and $74 \mathrm{kV}$ at a pressure of 4 bars, respectively. 


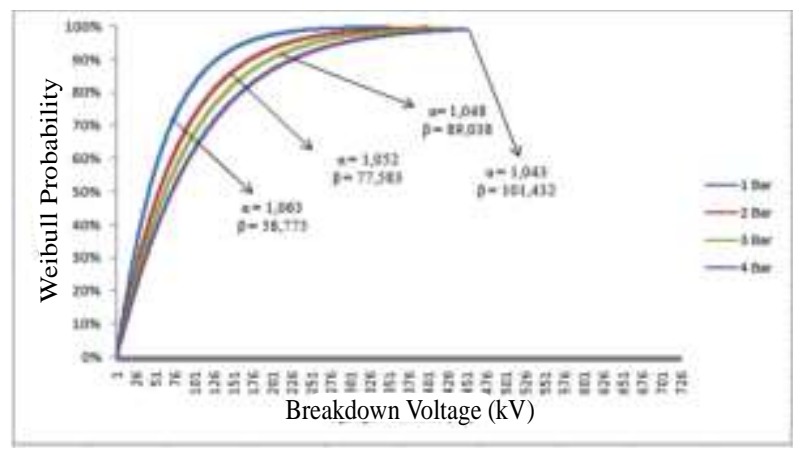

Figure 4. Curve for nitrogen gas $\left(\mathrm{N}_{2}\right)$ breakdown voltage with needle electrodes, the gap of $0.5 \mathrm{~cm}$ and gas pressure of $1-4$ bars

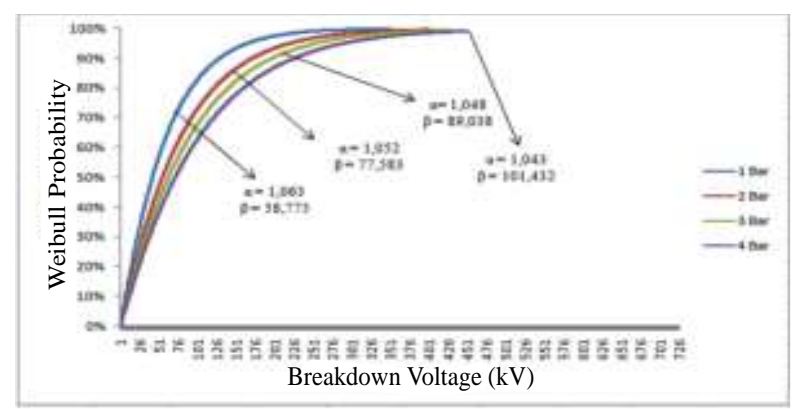

Figure 5. Curve for air breakdown voltage with needle electrodes, the gap of $0.5 \mathrm{~cm}$, gas pressure of 1-4 bars.

In figure 3, it can be seen that the air insulation breakdown voltage with sphere electrodes with the gap of $0.5 \mathrm{~cm}$, the Weibull probability of $100 \%$ is obtained when breakdown voltage of $130 \mathrm{kV}$ at 1 bar pressure, $250 \mathrm{kV}$ at a pressure of 2 bars, $350 \mathrm{kV}$ at a pressure of 3 bars and $400 \mathrm{kV}$ at a pressure of 4 bars, respectively. Figure 3 showed the Weibull probability of $50 \%$ was obtained for breakdown voltage of 18 $\mathrm{kV}$ at a pressure of 1 bar, $37 \mathrm{kV}$ at a pressure of 2 bars, $54 \mathrm{kV}$ at a pressure of 3 bars and $61 \mathrm{kV}$ at a pressure of 4 bars, respectively.

The insulation of nitrogen gas $\left(\mathrm{N}_{2}\right)$ with needle electrodes configuration with the gap of $0.5 \mathrm{~cm}$ in figure 4 , the Weibull probability of $100 \%$ is obtained when breakdown voltage of $150 \mathrm{kV}$ at 1 bar pressure, $200 \mathrm{kV}$ at a pressure of 2 bars , 300 $\mathrm{kV}$ on 3 bars pressure and $330 \mathrm{kV}$ at a pressure of 4 bars, respectively. Figure 4 shows the Weibull probability of $50 \%$ was obtained for breakdown voltage of $20 \mathrm{kV}$ at a pressure of 1 bar, $30 \mathrm{kV}$ at a pressure of 2 bars, $37 \mathrm{kV}$ at a pressure of 3 bars and $43 \mathrm{kV}$ at a pressure of 4 bars, respectively.

Base on figure 5 , it shows that the air insulation breakdown voltage with needle electrodes configuration, gap of $0.5 \mathrm{~cm}$, the Weibull probability of $100 \%$ is obtained when breakdown voltage of $150 \mathrm{kV}$ at 1 bar pressure, $200 \mathrm{kV}$ at a pressure of 2 bars, $220 \mathrm{kV}$ at a pressure of 3 bars and $300 \mathrm{kV}$ at a pressure of 4 bars, respectively. Figure 5 shows the Weibull probability of $50 \%$ was obtained breakdown voltage of $20 \mathrm{kV}$ at a pressure of 1 bar, $24 \mathrm{kV}$ at a pressure of 2 bars, $31 \mathrm{kV}$ at a pressure of 3 bars and $41 \mathrm{kV}$ at a pressure of 4 bars, respectively. Weibull probability of $50 \%$ at a pressure of 1-4 bar, it means that for 20 times test, will produce ten times breakdown voltage and ten times without breakdown. All figures are depicted the characteristic curves, and it can be seen that the breakdown voltage is directly proportional to the gas pressure. The Weibull distribution plot is suitable to find the probability of gas insulation breakdown.

\section{B. Data Analysis}

Refer to the data, and it was produced the directly proportional graphs. If the maximum gas pressure in the container, it will occur the significant breakdown voltage. If the maximum gap between the electrodes, it will also produce the highest breakdown voltage. The test results indicated that the breakdown voltage of sphere electrodes is much larger than the breakdown voltage of the needle electrodes with the same gas pressure and the same gap between the electrodes. It is because the sphere electrode has a uniform electric field, while the needle electrode does not have the electric field in uniform. From test results, insulating of nitrogen gas $\left(\mathrm{N}_{2}\right)$ and the insulation of the air showed that the breakdown voltage insulation nitrogen gas $\left(\mathrm{N}_{2}\right)$ is higher than the air in the sphere and needle electrodes with 1-4 bars pressure. This means that the dielectric strength of the insulation nitrogen gas $\left(\mathrm{N}_{2}\right)$ is greater than the dielectric strength of air insulation. Nitrogen gas $\left(\mathrm{N}_{2}\right)$ has a property such as cold and nitrogen gas is also able to extinguish the fire. This indicates that the nitrogen gas $\left(\mathrm{N}_{2}\right)$ is better used for insulating gas in the CB (circuit breaker) or switchgear compared with air.

\section{CONCLUSIONS}

The nitrogen gas $\left(\mathrm{N}_{2}\right)$ is one of the prospective material for alternative insulation material. Based on the analysis and discussion of the results, it can be concluded as listed below:

a) Breakdown voltage insulation of nitrogen gas $\left(\mathrm{N}_{2}\right)$ is more excellent than the insulation of air at a pressure of 1-4 bars, with sphere or needle electrodes and with a gap of 0.5 to $2.0 \mathrm{~cm}$.

b) The gas pressure of nitrogen $\left(\mathrm{N}_{2}\right)$ is proportional to the breakdown voltage with the sphere or needle electrodes with a gap of 0.5 to $2.0 \mathrm{~cm}$.

c) The breakdown voltage of sphere electrodes is larger than the breakdown voltage on the needle electrodes.

The Weibull distribution plot is suitable to find the probability of gas insulation breakdown

\section{ACKNOWLEDGMENT}

The authors would like to convey a great appreciation to LPPM Universitas Riau for financial support through Penelitian Dosen Muda 2018

\section{REFERENCES}

[1] Kumara L, "Efek Polaritas dan Fenomena Stres Tegangan Sebelum Kegagalan Isolasi pada Sela Udara Jarum-Plat", [skripsi], Surabaya, Fakultas Teknik, Institut Teknologi Sepuluh November, 2010.

[2] Abdel-Salam M, Hussein A, Ahdab E, Roshdy R, "High-Voltage Engineering Theory and Practice", Marlin OT, editor, Electrical and Computer Engineering, Colombus, The Ohio State University Department of Electrical Engineering, 2000.

[3] Cassanovas AM, J Cassanovas, "Decomposition of High-Pressure (400 $\mathrm{kPa}$ ) SF6-CO2, SF6-CO, SF6-N2-CO2, and SF6-N2-CO Mixture 
under Negative DC Coronas", Journal of Physics D. 38:1556-1564, 2005.

[4] Lim Dong-Young, Sungwoo Bae, "Study on Oxygen/Nitrogen Gas Mixtures for The Surface Insulation Performance in Gas Insulated Switchgear", IEEE Transactions on Dielectrics and Electrical Insulation, 22:1567-1576, 2015.

[5] Anggara S, "Pengaruh Curah Hujan pada Tegangan Bolak-Balik Lewat Denyar Isolator Gantung Keramik" [skripsi], Yogyakarta, Fakultas Teknik, Universitas Gadjah Mada, 2013.

[6] Ueno H, N Sakomoto, T Hoshida, H Nakayama, "Corona and Breakdown Characteristics between Sphere Electrode with a Protrusion and Plane Electrode under Negative Pulse Voltage in N2 Gas", IEEE Transactions on Dielectrics and Electrical Insulation, 11:1065-1072, 2004.

[7] Siswanto. "Analisa Perbandingan Nilai Tegangan Tembus Dielektrik Udara pada Kondisi Basah dengan Cairan Dominan Asam, Basa, Garam, Cairan Hujan di Wilayah Pantai, dan di Kawasan Industri dengan Elektroda Bola-Bola dan Elektroda Jarum-Jarum", Semarang, Fakultas Teknik, Universitas Diponegoro, 2013.
[8] Toyota Hiroyuki, Shigeyuki Z, Yotaro A, Shigeyasu M, Kunihiko H, "Gaseous Electrical Discharge Characteristics in Air and Nitrogen at Cryogenic Temperature", IEEE Transactions on Dielectrics and Electrical Insulation, 9:891-898, 2002.

[9] Naidu MS, V Kamaraju, "High Voltage Engineering", Second Edition, Amerika, The McGraw-Hill Companies, 1996.

[10] Nur Sugeng, Hamzah Berahim, "Analisis Pengaruh Keadaan Suhu Terhadap Tegangan Tembus AC dan DC pada Minyak Transformator", Jurnal Teknik Elektro. 1:93-99, 2009.

[11] L. Bonggas, "Dasar-Dasar Teknik Pengujian Tegangan Tinggi", Edisi Kedua, Jakarta, Penerbit Erlangga, 2012.

[12] Tsuyoshi Kiyan, Takeshi Ihara, Suguru Kameda, Tomohiro Furusato, Masanori Hara, Hidenori Akiyama, "Weibull Statistical Analysis of Pulsed Breakdown Voltages in High-Pressure Carbon Dioxide Including Supercritical Phase", IEEE Transactions on Plasma Science, Vol. 39, Issue: 8, Page: $1729-1735,2011$. 